\title{
Hawgent Dynamic Mathematics Software to Teach Line and Angle
}

\author{
Xiangjie Zhang ${ }^{1 *}$, Ying Zhou ${ }^{2}$, Tommy Tanu Wijaya ${ }^{3}$ \\ 1,2,3 Departement of Mathematics Education, Guangxi Normal University, Guilin, China; \\ 1949221694@qq.com; 2 799936971@qq.com; ${ }^{3 *}$ tommytanu@foxmail.com
}

Article Info: Sent: May 3, 2020 ; Revised: May 23, 2020; Accepted: September 16, 2020

How to Cite: Zhang, X., Zhou, Y., \& Wijaya, T. T. (2020). Hawgent Dynamic Mathematics Software to Teach Line and Angle. JNPM (Jurnal Nasional Pendidikan Matematika) 4(2), 237-247.

\begin{abstract}
This research aims to use Hawgent dynamic mathematics software to create a learning media on lines and angles based on students' weaknesses and difficulties when studying the material using traditional methods. This research is development research using the ADDIE model. Instruments in the form of validation sheets and practicality. The results show that learning media using Hawgent dynamic mathematics software can explain basic concepts in the material of lines and angles. Implementation in learning and teacher and student responses show that Hawgent learning media positively affects learning the concept of lines and angles. Students in the experimental class are more active when explaining the material on lines and angles using Hawgent dynamic mathematics software. So that this learning media can help students in teaching and learning activities in class.
\end{abstract}

Keywords: Hawgent dynamic mathematics software, Line and angle, ICT.

\begin{abstract}
Abstrak. Tujuan penelitian ini adalah menggunakan hawgent dynamic mathematics software untuk membuat suatu media pembelajaran pada materi garis dan sudut berdasarkan kesulitan yang dihadapi siswa dengan metode tradisional. Metode penelitian ini adalah pengembangan dengan model ADDIE. Instrumen berupa lembar validasi dan praktikalitas. Hasil menunjukan bahwa media pembelajaran menggunakan hawgent dynamic mathematics software dapat digunakan untuk menjelaskan konsep dasar pada materi garis dan sudut. Implementasi dalam pembelajaran serta tanggapan guru dan siswa menunjukan bahwa media pembelajaran hawgent mempunyai efek positif dalam mempelajari konsep garis dan sudut. Siswa pada kelas eksperimen lebih aktif ketika guru menjelaskan materi garis dan sudut menggunakan hawgent dynamic mathematics software. Sehingga media pembelajaran ini dapat membantu siswa dalam kegiatan belajar mengajar di kelas.
\end{abstract}

\section{Introduction}

Mathematics is an important part of human civilization (Dini, Wijaya, \& Sugandi, 2018). Geometry is a branch of mathematics that deals with points, lines, plane shapes, Spaces, spatial shapes, and relationships (Kushwaha, Chaurasia, \& Singhal, 2014; Lognoli, 2017). The ability of students to understand geometry is lower than that of other subjects of mathematics. 
Learning patterns can affect students' understanding of mathematics (Vavougios \& Karakasidis, 2008; Wijaya, Dewi, Fauziah, \& Afrilianto, 2018; Zulfah, Astuti, Surya, Marta, \& Wijaya, 2020). To create a learning environment that encourages learners, teachers can create new and innovative learning opportunities that may be greater to solve cooperation problems than in competitive or personalized learning environments. The combination of learning mode can improve students' academic performance (Listiawan, Purwanto, As'Ari, \& Muksar, 2018; Oner, 2020; Sukaesih, Ridlo, \& Saptono, 2019). Due to this matter, it is necessary to develop a technology-based learning media to help students understand an abstract mathematics concept to be easier for students to understand the basic concept of mathematics.

Lines and angles are the basic concepts of geometry. To better understand geometry, students must have a good understanding of lines and angles. Space in Euclidean geometry, people will position the abstract as the "point", and the connection path between two points is called "line", there are two kinds of the definition of "Angle", a public endpoints control one raises two rays of graphics. The second is a radiographic OA by original position $\mathrm{O}$ rotates around its endpoint to another location OB graphics. three lines intersect, except for the intersection of three lines and a point; there are other cases "line and angle."

In the traditional line and angle teaching, due to the lack of in-depth explanation and display of knowledge's inherent attributes. Students usually confuse the existence conditions of alternate interior angles and the same side interior angles after learning parallel lines. They think that they can only exist when they are parallel (Salim, 2019; Utami, Kusmayadi, \& Usodo, 2017). This shows that students did not understand "line and angle" and did not abstract the concepts of alternate interior angles from it, which hindered the subsequent geometric teaching.

With the continuous development of information technology, it is found that teachers' use of ICT in class has a significant positive effect on students' math literacy and computer test scores, and the use of dynamic mathematics software has a better effect (Bernard \& Chotimah, 2018; Rohaeti, Bernard, \& Primandhika, 2019; Wijaya, Ying, Chotimah, \& Bernard, 2020; Wijaya, Ying, Cunhua, \& Zulfah, 2020).

Hawgent dynamic mathematics software is a math software from Guangzhou, China, which is designed according to practitioners and scholars' needs in the field of education (Wijaya, Purnama, \& Tanuwijaya, 2020; Wijaya, Ying, \& 
Purnama, 2020a). Compared with the familiar geometric drawing board and other dynamic mathematical software, Hawgent in many aspects of innovation and flexible and convenient operation, powerful teaching function, rich curriculum resources, and other advantages. The following three aspects of outstanding characteristics: Menus and commands can be customized, internal and extended parts are rich, mathematical objects and relationships can be copied. Hawgent dynamic software not only has the function of mathematical objects in mathematical learning, but also can make the static geometric relationship dynamic, through flicker, movement, and other changes can arouse students' interest in learning, highlighting the essence of the formation (Cunhua, Ying, Qunzhuang, \& Wijaya, 2019). Previously, a few learning media has been developed using hawgent dynamic mathematics software to help teachers teach the basic concept on mathematics (Wijaya, 2021; Wijaya, Ying, \& Purnama, 2020b). The aim is to improve students' learning interests and outcomes (Wijaya, Sukma, Purnama, \& Tanuwijaya, 2020).

What will be presented in this study is the initial part of learning geometry for students. Hawgent dynamic design is also the first complex figure given to junior high school students, which plays a role in connecting the previous and following elements in all geometry learning. Therefore, the teaching design of Line and angle is particularly important for teachers. This research will develop a learning media using hawgent dynamic mathematics software on Line and angle. This way, we can also see the impact of learning media on the students' learning outcome.

\section{Method}

This study's research method uses the ADDIE model for research and development (Abadi, Asih, \& Jupri, 2018; Bernard, Sumarna, Rolina, \& Akbar, 2019). The model aims to solve problems systematically according to requirements and problem characteristics (Zainuddin, Hasanah, Salam, Misbah, \& Mahtari, 2019). Research methods include analysis, design, development, implementation, and evaluation (Kristanto, Mustaji, Mariono, Sulistiowati, \& Nuryati, 2018). The steps for the ADDIE model are shown in figure 1. 

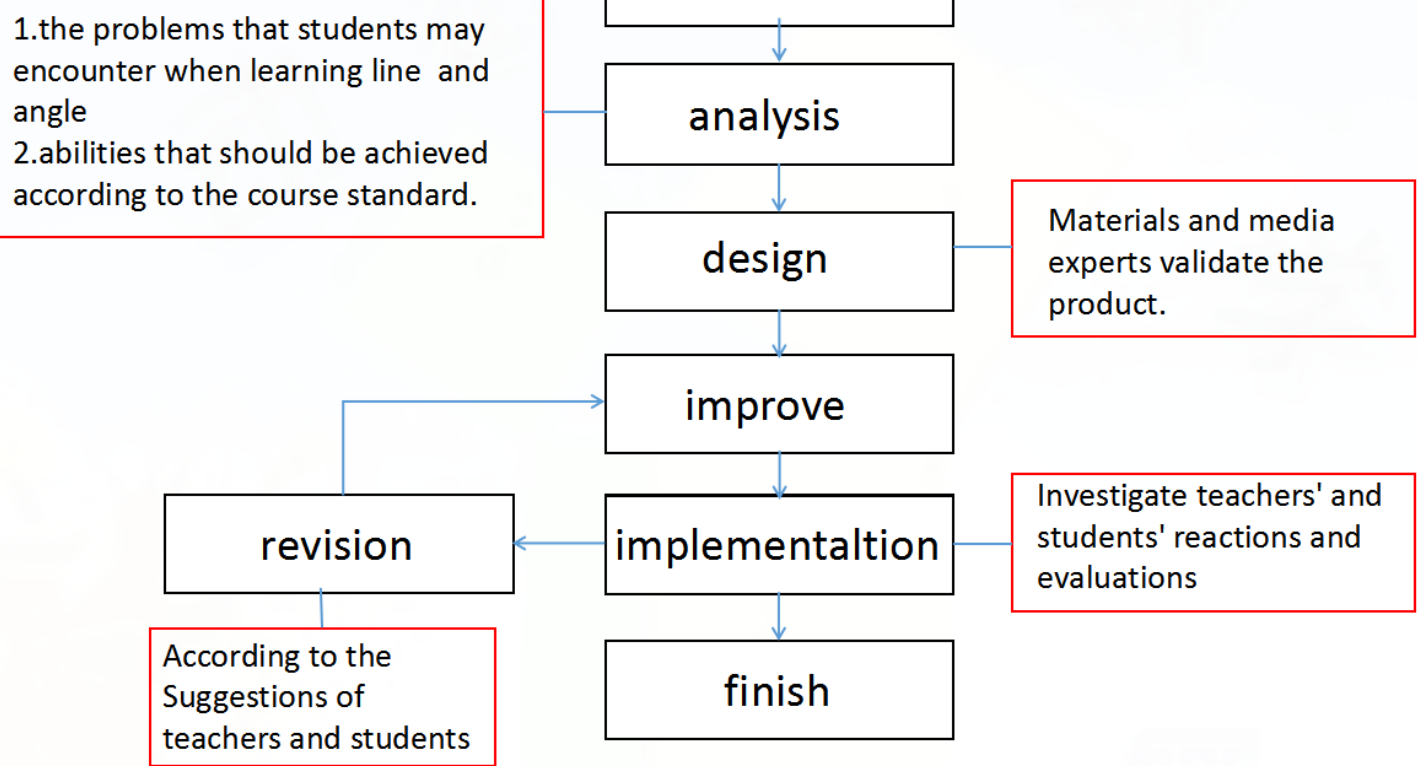

Figure 1. Steps to make the learning media by ADDIE model

The steps for making the learning media are shown in figure 1. In the analysis phase, the researchers will analyze the difficulties students face in learning the Line and angle at school and find out the abilities that meet the curriculum's standards. In the design phase, the Hawgent dynamic mathematics software will be used to make the learning media. Upon completing the learning media, the learning media will be validated by three materials and three media experts from China. After the media has been modified according to the materials and the opinions of media experts, learning media will be implemented in Cianjur, Indonesia. In the implementation phase, researchers will travel to schools and use the Hawgent dynamic software as a learning medium to ask teachers and students for their reactions and evaluations of learning media. In the improvement stage, the learning media is modified according to the suggestions of teachers and students. This research will only focus on learning the media's design until the learning media are verified to be worth using.

The data in this research is collected in a formative way, with always evaluating every data. The data collected and evaluated are the evaluation of difficulties teachers face when explaining Line and angle using ICT, resulting from the media expert, resulting from the material expert and implementation result when using Hawgent dynamic mathematics software for students Cianjur, Indonesia. 
In this study, the data of media and material experts will be collected by means of a questionnaire survey. The data provided by the media and materials experts will be analyzed by calculating the average score given by the media and materials experts. The average score was then classified according to the criteria shown in table 1.

Table 1. Assessment criteria of learning media

\begin{tabular}{lll}
\hline Score & Validity criteria & Description \\
\hline $3.26 \leq \mathrm{x} \leq 4.00$ & Valid/very good & No revision \\
$2.51 \leq \mathrm{x} \leq 3.26$ & Valid enough & Need a little revision \\
$1.76 \leq \mathrm{x} \leq 2.51$ & Not very valid & Need a lot of revision \\
$1.00 \leq \mathrm{x} \leq 1.76$ & Not valid & Not to be used \\
\hline
\end{tabular}

\section{Results and discussion}

\section{Analysis}

In mathematics, there are names, labels, and conventions that are arbitrary to students. Therefore, students must remember them so that they can convey their ideas to others. An example of anything is "a line has 180 degrees". The teacher could not explain why it was 180 degrees because it was a convention, and that was why there was no reason behind the random thing. Therefore, teachers can only tell students random things that go into the field of students' memory.

On the other hand, teachers should not tell students what is necessary. Otherwise, students will remember them. Students should work out what is needed so that they can recognize and provide reasons. For example, students can calculate the missing angles of a triangle, in which there are two angles. To figure this out, students must be aware that, therefore, everything necessary is in the realm of consciousness.

\section{learning media design}

In the learning media making phase, Hawgent dynamic mathematics software ipractitioners'cording to the initial observation on Line and angle and the national curriculum. Learn media with animations, such as flashing or moving pictures, so that it can capture students' interest. An example of learning media using the Hawgent dynamic mathematics software is shown in figure 2. 

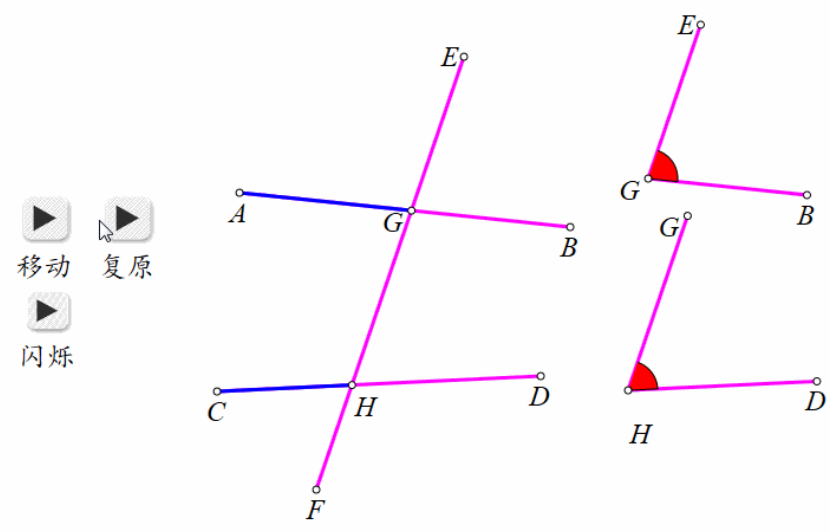

(a)

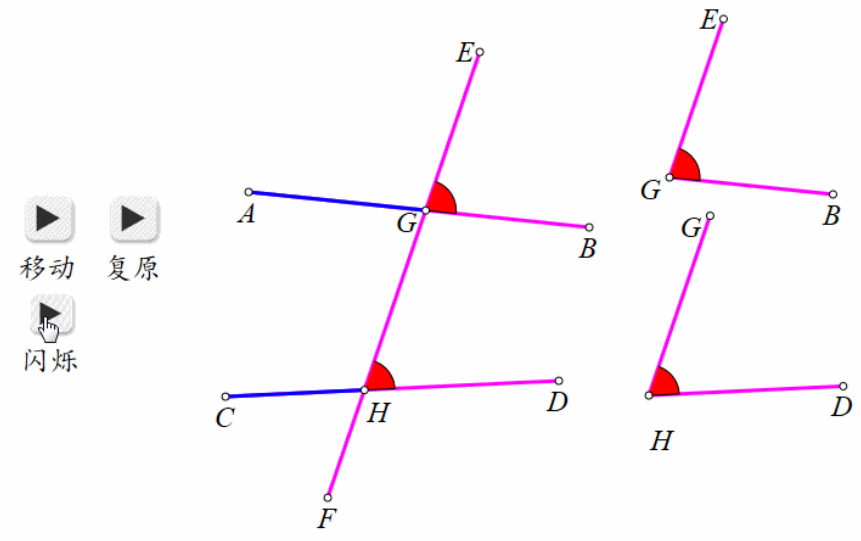

(b)

Figure 2. (a) Separate the angles to be observed (b) Flicker the Angle to be observed

Figure 2 shows that there are two different colors dividing the three line segments. By moving, the same side Angle to be observed can be separated from it for easy observation. Compared with the traditional teaching process, this operation simplifies the cognitive process of Line and angle. In addition, the angles before and after separation can also be compared by marking the angles. Line and angle can be deeply understood in different forms.

In traditional teaching, teachers teach by drawing pictures on the blackboard and then marking the corners. As the teaching process is single and the focus is not prominent enough, students do not have the enthusiasm for deep learning in the learning process, which may cause the following problems: unable to correctly understand the three-line octagonal structure, unable to express the process of methods, difficulty in extracting relevant concepts, etc. The process of applying Hawgent dynamic mathematics software can be roughly divided into the following three parts: the first and third octagonal 
dynamic display. Teachers display learning media to attract students' interest. In the process of explanation, the key points are highlighted dynamically to facilitate students' observation. Second, students operate. Students can carry out the simulation operation according to the teacher's demonstration, strengthen the hands-on ability, and deepen the understanding of the threeline octagonal structure. Third, teachers guide students to understand relevant concepts and promote in-depth learning. The specific implementation process is shown in table 2.

Application of Hawgent dynamic mathematics software for teaching will have the following effects: first, dynamic display, attract interest. Dynamic Angle separation will attract students' attention, and then with the teacher's appropriate explanation, deepen students' understanding. Second, the method process is operational. Teachers can show the three-line octagon and let students operate by themselves to strengthen the process of memory. Finally, the abstract concept is supplemented by a vivid and intuitive dynamic effect to help students to enhance the storage and extraction of relevant conceptual information.

Table 2. Learning Media Implementation Process

\begin{tabular}{|c|c|c|c|}
\hline Process & Content & Purpose & Time \\
\hline $\begin{array}{l}\text { Introduction (Discuss } \\
\text { relevant knowledge) }\end{array}$ & $\begin{array}{l}\text { Learn about lines and } \\
\text { angles } \\
\text { discussion }\end{array}$ & Start course & 5 minutes \\
\hline Main content & $\begin{array}{l}\text { The teacher shows the } \\
\text { dynamic angle } \\
\text { movement and } \\
\text { flashing process, and } \\
\text { the teacher explains it } \\
\text { appropriately }\end{array}$ & $\begin{array}{lr}\text { Attract } & \text { students' } \\
\text { attention } & \text { and } \\
\text { emphasize } & \text { the } \\
\text { important points } & \end{array}$ & 15 minutes \\
\hline $\begin{array}{l}\text { (discussion) } \\
\text { operation }\end{array}$ & $\begin{array}{l}\text { The student conducts } \\
\text { the operation imitation } \\
\text { to the product through } \\
\text { the teacher's } \\
\text { instruction }\end{array}$ & $\begin{array}{l}\text { Improve the ability to } \\
\text { work and understand } \\
\text { the relationship } \\
\text { between lines and } \\
\text { angles }\end{array}$ & 15 minutes \\
\hline $\begin{array}{l}\text { (Conclusion) } \\
\text { formation }\end{array}$ & $\begin{array}{l}\text { The teacher guides the } \\
\text { students to make a } \\
\text { conceptual summary } \\
\text { of the intuitive lines } \\
\text { and angles }\end{array}$ & $\begin{array}{l}\text { Form the concept of } \\
\text { opposite lines and } \\
\text { angles }\end{array}$ & 5 minutes \\
\hline
\end{tabular}

\section{Validity Result of Interactive Multimedia}

After designing the learning media on probability using Hawgent dynamic mathematics software, the next stage is for the media to be validated by the media and material experts to see the learning media's effectiveness. 
Three materials and three media experts were invited to rate the learning media according to the criteria in table 1 . The media experts rated the content in four aspects: the accuracy of the way the material is presented, the completeness of the components in each chapter of teaching material, the problem-solving steps, the design, and the animation. For the accuracy of the way the material is presented, the average media expert score is 4.33 , classified as valid. For the completeness of the components in each chapter of teaching material, the average score of the media expert is 4 , which can be classified as valid. For problem-solving steps, the average media expert scored 3.66, which can be classified as effective. For design and animation, the average media expert score is 4.33 , classified as valid. The specific score is shown in table 3.

Table 3. Assessment From Learning Media Expert

\begin{tabular}{lllllll}
\hline No & Statement & Expert & Average & Category \\
& & 1 & 2 & 3 & & \\
\hline 1 & $\begin{array}{l}\text { The accuracy of the way the material is presented } \\
4\end{array}$ & 4 & 5 & 4.33 & Valid \\
2 & $\begin{array}{l}\text { Completeness of the components in each chapter of } \\
\text { teaching material }\end{array}$ & 4 & 4 & 4 & Valid \\
& $\begin{array}{l}\text { Problem solving steps } \\
4\end{array}$ & & & & & \\
Design and animation & 4 & 3 & 4 & 3.66 & valid \\
& 4 & 4 & 5 & 4.33 & Valid \\
\hline
\end{tabular}

Similar to media experts, material experts will also rate the following four areas: the accuracy of the selection of summary content, clarity of examples given, conformity between the final chapter test and learning objectives, clarity of material description. For the accuracy of selecting summary content, the average media expert score is 3.33, which can be classified as valid. For clarity of examples given, the average score of the media expert is 4.6, which can be classified as valid. For conformity between the final chapter test and learning objectives, the average media expert scored 3.66, which can be classified as effective. For clarity of material description, the average media expert score is 4.66 , which can be classified as valid. The specific score is shown in table 4.

Table 4. Assessment from learning material expert

\begin{tabular}{|c|c|c|c|c|c|c|}
\hline \multirow[t]{2}{*}{ No } & \multirow[t]{2}{*}{ Statement } & \multicolumn{3}{|c|}{ Expert } & \multirow[t]{2}{*}{ Average } & \multirow[t]{2}{*}{ Category } \\
\hline & & 1 & 2 & 3 & & \\
\hline 1 & The accuracy of the selection of summary content & 4 & 3 & 3 & 3.33 & Valid \\
\hline 2 & Clarity of examples given & 4 & 5 & 5 & 4.66 & Valid \\
\hline 3 & $\begin{array}{l}\text { Conformity between the final chapter test and learning } \\
\text { objectives. }\end{array}$ & 4 & 3 & 4 & 3.66 & Valid \\
\hline 4 & Clarity of material description. & 4 & 5 & 5 & 4.66 & Valid \\
\hline
\end{tabular}




\section{Practicality of interactive multimedia}

After media and materials experts declared learning media to be feasible and valid, the researchers used Hawgent dynamic mathematics software to teach the Line and angle course.

Table 5. Students' Ability In Answering The Post-Test Problem

\begin{tabular}{llll}
\hline \multirow{2}{*}{ No } & \multicolumn{1}{c}{ Findings } & $\begin{array}{c}\text { Number of } \\
\text { Students }\end{array}$ & Percentage \\
\hline \multirow{2}{*}{1} & Understanding the meaning of Line & & \\
& and angle & 28 & $87.50 \%$ \\
2 & Explaining how to get the result & 26 & $81.25 \%$ \\
3 & Linking Line and its angle & 26 & $81.25 \%$ \\
4 & Work process method & 24 & $75.00 \%$ \\
5 & Evaluate the proof of a result & 29 & $90.63 \%$ \\
6 & Describing angle according to data & 30 & $93.75 \%$ \\
\hline
\end{tabular}

Table 5 shows that the students' post-test results are very satisfactory. The students' post-test includes six aspects. According to another research, teaching using technology can make students understand the topic better and improve their learning ability (Tan, Zou, Wijaya, Suci, \& Dewi, 2020; Wijaya, Ying, Cunhua, \& Zulfah, 2020). Therefore, using Hawgent dynamic mathematics software to develop Line and angle learning media is an interesting and effective way to learn.

The use of technology in teaching and learning activities has many advantages than traditional learning. Research on the development of learning media and technology-based learning media are still developing until now. Many learning media can be used to teach and learn activities such as Ipad, cellphones, and so on (Al-Mashaqbeh, 2016). Other researchers can continue their research to use mathematics software as a learning media in the classroom in further study.

\section{Conclusion}

The development of learning media has been recognized as useful by media and materials experts, and the post-test results of students are ideal. Therefore, using Hawgent dynamic mathematics software to develop Line and angle learning media is an interesting and effective way for students to learn. Based on the research results, it is concluded that a dynamic learning media is needed in mathematics teaching, such as the course designed by Hawgent dynamic mathematics software, to help teachers explain basic concepts and deepen students' understanding. 


\section{References}

Abadi, M. K., Asih, E. C. M., \& Jupri, A. (2018). The Development of Interactive Mathematics Learning Material Based on Local Wisdom with .swf Format. Journal of Physics: Conference Series, 1013(1). https://doi.org/10.1088/1742-6596/1013/1/012131.

Al-Mashaqbeh, I. F. (2016). IPad in elementary school math learning setting. International Journal of Emerging Technologies in Learning, 11(2), 48-52. https://doi.org/10.3991/ijet.v11i02.5053.

Bernard, M., \& Chotimah, S. (2018). Improve student mathematical reasoning ability with open-ended approach using VBA for powerpoint. AIP Conference Proceedings, 2014(September). https://doi.org/10.1063/1.5054417.

Bernard, M., Sumarna, A., Rolina, R., \& Akbar, P. (2019). Development of high school student work sheets using VBA for microsoft word trigonometry materials. Journal of Physics: Conference Series, 1315(1). https://doi.org/10.1088/1742-6596/1315/1/012031.

Cunhua, L., Ying, Z., Qunzhuang, O., \& Wijaya, T. T. (2019). Mathematics course design based on six questions cognitive theory using hawgent dynamic mathematic. Journal On Education, 02(01), 36-44.

Dini, M., Wijaya, T. T., \& Sugandi, A. I. (2018). Pengaruh Self Confidence Terhadap Kemampuan Pemahaman Matematik Siswa Smp. Jurnal Silogisme, 3(1), 1-7.

Kristanto, A., Mustaji, Mariono, A., Sulistiowati, \& Nuryati, D. W. (2018). Developing Media Module Proposed to Editor in Editorial Division. Journal of Physics: Conference Series, 947(1). https://doi.org/10.1088/1742-6596/947/1/012054.

Kushwaha, R. C., Chaurasia, P. K., \& Singhal, A. (2014). Impact on students' achievement in teaching mathematics using geogebra. Proceedings - IEEE 6th International Conference on Technology for Education, T4E 2014, 134-137. https://doi.org/10.1109/T4E.2014.54.

Listiawan, T., Purwanto, P., As'Ari, A. R., \& Muksar, M. (2018). Mathematics Teachers Technological Content Knowledge (TCK) in using Dynamic Geometry Software. Journal of Physics: Conference Series, 1114(1). https://doi.org/10.1088/1742-6596/1114/1/012121.

Lognoli, D. (2017). The area of the disk in Middle School Grade by GeoGebra. International Journal of Emerging Technologies in Learning, 12(11), 28-40. https://doi.org/10.3991/ijet.v12.i11.6834.

Oner, D. (2020). A virtual internship for developing technological pedagogical content knowledge. Australasian Journal of Educational Technology, 36(2), 27-42. https://doi.org/10.14742/ajet.5192.

Rohaeti, E. E., Bernard, M., \& Primandhika, R. B. (2019). Developing interactive learning media for school level mathematics through open-ended approach aided by visual basic application for excel. Journal on Mathematics Education, 10(1), 59-68. https://doi.org/10.22342/jme.10.1.5391.59-68.

Salim, S. S. (2019). Identifying students' understanding of missing angles in parallel lines: A case study of year 7 students in the United Kingdom. Journal of Physics: Conference Series, 1321(2). https://doi.org/10.1088/1742-6596/1321/2/022102.

Sukaesih, S., Ridlo, S., \& Saptono, S. (2019). Development of biology teaching management textbooks based on competency and conservation to maximize Pedagogical and Content Knowledge (PCK) the prospective teachers. Journal of Physics: Conference Series, 1321(3). https://doi.org/10.1088/1742-6596/1321/3/032114.

Tan, S., Zou, L., Wijaya, T. T., Suci, N., \& Dewi, S. (2020). Improving student creative thinking ability with problem based learning approach using hawgent. Journal on Education, 02(04), 303-312.

Utami, N. S., Kusmayadi, T. A., \& Usodo, B. (2017). Learning Line and Angle at 7th Grade Students. Journal of Physics: Conference Series, 895(1). https://doi.org/10.1088/1742- 
6596/895/1/012037.

Vavougios, D., \& Karakasidis, T. E. (2008). Application of ICT technology in physics education: Teaching and learning elementary oscillations with the aid of simulation software. International Journal of Emerging Technologies in Learning, 3(2), 53-58.

Wijaya, T. T. (2021). How chinese students learn mathematics during the coronavirus pandemic. International Journal of Educational Research and Innovation (IJERI), 15, 1-16. https://doi.org/https://doi.org/10.46661/ijeri.4950.

Wijaya, T. T., Dewi, N. S. S., Fauziah, I. R., \& Afrilianto, M. (2018). Analisis Kemampuan Pemahaman Matematis Siswa Kelas IX Pada Materi Bangun Ruang. UNION: Jurnal Ilmiah Pendidikan Matematika, 6(1), 19-28. https://doi.org/10.30738/.v6i1.2076.

Wijaya, T. T., Purnama, A., \& Tanuwijaya, H. (2020). Pengembangan Media Pembelajaran Berdasarkan Konsep Tpack pada Materi Garis dan Sudut Menggunakan Hawgent Dynamic Mathematics Software. JPMI - Jurnal Pembelajaran Matematika Inovatif, 3(3), 205214. https://doi.org/10.22460/jpmi.v1i3.205-214.

Wijaya, T. T., Sukma, M., Purnama, A., \& Tanuwijaya, H. (2020). Pengembangan media pembelajaran berbasis tpack menggunakan hawgent dynamic mathematics software. Journal of Elementary Education, 03(03), 64-72.

Wijaya, T. T., Ying, Z., Chotimah, S., \& Bernard, M. (2020). Hawgent dynamic mathematic software as mathematics learning media for teaching quadratic functions Hawgent dynamic mathematic software as mathematics learning media for teaching quadratic functions. Journal of Physics: Conference Series, 1592(1). https://doi.org/10.1088/17426596/1592/1/012079.

Wijaya, T. T., Ying, Z., Cunhua, L., \& Zulfah. (2020). Using vba learning media to improve students' mathematical understanding ability. Journal On Education, 02(02), 245-254.

Wijaya, T. T., Ying, Z., \& Purnama, A. (2020a). The empirical research of hawgent dynamic mathematics technology integrated into teaching. Journal Cendekia: Jurnal Pendidikan Matematika, 04(01), 144-150.

Wijaya, T. T., Ying, Z., \& Purnama, A. (2020b). Using Hawgent Dynamic Mathematics Software in Teaching Trigonometry. International Journal of Emerging Technologies in Learning, 15(10), 215-222. https://doi.org/10.3991/ijet.v15i10.13099.

Zainuddin, Hasanah, A. R., Salam, M. A., Misbah, \& Mahtari, S. (2019). Developing the interactive multimedia in physics learning. Journal of Physics: Conference Series, 1171(1). https://doi.org/10.1088/1742-6596/1171/1/012019.

Zulfah, Astuti, Surya, Y. F., Marta, R., \& Wijaya, T. T. (2020). Measurement of mathematics problems solving ability using problem based mathematics question Measurement of mathematics problems solving ability using problem based mathematics question. Journal of Physics: Conference Series, 1613(1). https://doi.org/10.1088/17426596/1613/1/012026. 